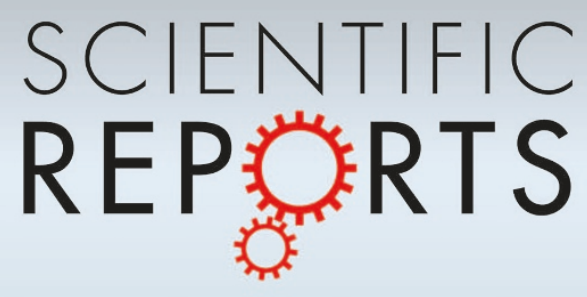

\title{
OPEN \\ An MFC-Based Online Monitoring and Alert System for Activated Sludge Process
}

SUBJECT AREAS:

ENVIRONMENTAL

BIOTECHNOLOGY

POLLUTION REMEDIATION

Received

14 July 2014

Accepted

7 October 2014

Published

27 October 2014

Correspondence and requests for materials should be addressed to

Y.M. (yangmu@ustc. edu.cn) or H.Y. (hqyu@ ustc.edu.cn)

\author{
Gui-Hua $X u^{1,2}$, Yun-Kun Wang ${ }^{1}$, Guo-Ping Sheng ${ }^{1}$, Yang Mu' \& Han-Qing Yu'
}

${ }^{1}$ CAS Key Laboratory of Urban Pollutant Conversion, Department of Chemistry, University of Science and Technology of China, Hefei 230026, China, ${ }^{2}$ Chongqing Institute of Green and Intelligent Technology, Chinese Academy of Sciences, Chongqing 400714, China.

In this study, based on a simple, compact and submersible microbial fuel cell (MFC), a novel online monitoring and alert system with self-diagnosis function was established for the activated sludge (AS) process. Such a submersible MFC utilized organic substrates and oxygen in the AS reactor as the electron donor and acceptor respectively, and could provide an evaluation on the status of the AS reactor and thus give a reliable early warning of potential risks. In order to evaluate the reliability and sensitivity of this online monitoring and alert system, a series of tests were conducted to examine the response of this system to various shocks imposed on the AS reactor. The results indicate that this online monitoring and alert system was highly sensitive to the performance variations of the AS reactor. The stability, sensitivity and repeatability of this online system provide feasibility of being incorporated into current control systems of wastewater treatment plants to real-time monitor, diagnose, alert and control the AS process.

ctivated sludge (AS) process is one of the most widely used technologies in wastewater treatment ${ }^{1}$. Since AS process is sensitive to the fluctuations of wastewater quantity and environmental instability ${ }^{2,3}$, it is crucial to real-time monitor its status in order to achieve better control and performance ${ }^{4}$. A significant number of chemical, physical and electrochemical approaches have been established to monitor the variation of ammonia nitrogen, COD (chemical oxygen demand), DO (dissolved oxygen), pH and temperature as well as other parameters in AS processes. ${ }^{5}$. However, each of these methods can only accurately determine the value of one specific parameter and cannot be able to provide sufficient information to monitor the overall status of the AS process, especially under various unstable conditions ${ }^{6,7}$.

Microbial fuel cell (MFC) technology has been intensively investigated as it is able to recover energy through treating wastewater ${ }^{8-10}$. In MFCs, microorganisms oxidize organic matter and release electrons at anode, while the terminal electron acceptors (e.g., $\mathrm{O}_{2}$ ) are reduced by reacting with the electrons at cathode ${ }^{11-13}$. Two electrodes are connected by a wire containing a load, which results in the generation of electric voltage. Recently MFC-based biosensors have been successfully developed to determine BOD (biological oxygen demand) ${ }^{6,14}, \mathrm{DO}^{7}$, volatile fatty acids $^{15}$ and toxicity ${ }^{16}$ of water samples. Although in some cases a close relationship between the concentration of the measuring object and MFC signal was obtained, previous studies mainly focused on detecting one particular parameter using MFC technology. However, due to the high complexity of AS process and the unclear interrelations of many involved parameters, such a single "biosensor" technology is not sufficient for on-line monitoring the status of the AS process. Moreover, none of these MFC biosensors had diagnosis and alert functions when suffering potential risks for AS process. In addition, most of previous MFC-type biosensors adopted cation exchange membrane (CEM) as the separator between anodic and cathodic chambers, resulting in a decrease in anolyte $\mathrm{pH}$, which is detrimental to the biological activity at the anode ${ }^{6}$.

Therefore, the present study aimed at developing a novel monitoring and alert system for the AS process, which was composed of a single-chamber MFC, a signal acquisition subsystem, and an alert subsystem with selfdiagnosis function. The compact single-chamber MFC without CEM, the core of the online system, was assembled and submersed into an AS reactor. The organic substrates and oxygen in the AS reactor were utilized as the electron donor and acceptor respectively by the MFC, which was used to record the variations of the AS reactor. The new alert subsystem with self-diagnosis function was established based on the statistical analysis and logic judgment programs in a Lab View virtual instrument platform. In order to evaluate the reliability and sensitivity of this online monitoring and alert system, various shock tests were imposed to the AS reactor and the corresponding responses of the submersible MFC were examined. In this way, a new online monitoring and alert system for AS process was established. 


\section{Results}

Stable performance of AS and MFC. After 8-d operation, the AS reactor reached its steady state, and the removal efficiencies of both $\mathrm{COD}$ and $\mathrm{NH}_{4}{ }^{+}-\mathrm{N}$ kept at $90.2 \pm 4.1 \%$ and $96.5 \pm 3.2 \%$, respectively (Fig. 1). The concentrations of SS and VSS were $4516 \pm 282$ and 3657 $\pm 546 \mathrm{mg} / \mathrm{L}$, respectively, while the DO concentration was within 4.4-5.1 $\mathrm{mg} / \mathrm{L}$ in the AS reactor. On the other hand, the MFC voltage reached $0.41 \pm 0.02 \mathrm{~V}$ after 30 -d operation and then kept stable (Fig. 1). Furthermore, the MFC-based online monitoring system was operated stably for 6 months without any additional maintenance (Fig. 1).

To further examine the MFC performance, the polarization curves were determined (Fig. S1). The open circuit voltage of the MFC was $0.88 \mathrm{~V}$ (Fig. S1A), whereas the maximum power density was $4.7 \mathrm{~W} /$ $\mathrm{m}^{3}$ (Fig. S1B). The power outputs and current of this study were similar with those in the previous studies in which membrane-less MFCs were used ${ }^{13,17}$. The internal resistance of the MFC was calculated as $34.5 \pm 2.4 \Omega$ by the slope of polarization curve, while the CE (coulombic efficiency) of the MFC was $6.23 \%$.

Organic overloading shock. In the 5 -h tenfold organic overloading (P1 in Fig. 2), the COD concentration in the AS effluent substantially increased from $22 \pm 2.1$ to $386 \pm 15.6 \mathrm{mg} / \mathrm{L}$, while the effluent $\mathrm{NH}_{4}{ }^{+} \mathrm{N}$ slightly increased from $0.6 \pm 0.21$ to $5.3 \pm 1.2 \mathrm{mg} / \mathrm{L}$ (Fig. 2A). On the contrary, the DO concentration decreased from $5.1 \pm 0.3$ to $0.2 \pm 0.1 \mathrm{mg} / \mathrm{L}$ in the AS reactor. Simultaneously, the MFC had a quick response to this shock. The variation of the MFC voltage rapidly dropped from $-0.005 \pm 0.0018$ to $-0.24 \pm 0.0038 \mathrm{~V}$ (Fig. 2B), while the anode potential decreased by $0.0749 \mathrm{~V}$ (Table $\mathrm{S} 1$ ). As a consequence, a lasting warning signal was provided by the alert system throughout P1. After the overloading shock was terminated, the variation of MFC voltage slowly returned back to $0.0041 \pm 0.0021 \mathrm{~V}$ after $13 \mathrm{~h}$ (P2 in Fig. 2B). During the P3 period, the variation of the MFC voltage approached zero and consequently the warning signal was stopped. This implies that the AS reactor had restored to a new steady state, as evidenced by the low AS reactor effluent COD level.

Ammonia overloading shock. Since nitrifying bacteria in AS grow slowly and are highly sensitive, it is important to monitor the ammonia nitrogen removal performance of AS systems. In general, the production of MFC voltage is not directly linked with the ammonium concentration. However, a high ammonia concentration could increase DO consumption and consequently decrease DO concentration in the AS reactor. Since the MFC adopted $\mathrm{O}_{2}$ as terminal electron acceptor in the online system, the variation of MFC voltage was able to have a quick response to the ammonium overloading shock.

In the $5-\mathrm{h} \mathrm{NH}_{4}{ }^{+}-\mathrm{N}$ overloading shock, the variation trend of MFC voltage was highly consistent in two repeated experiments (Fig. 3). The MFC voltage variation decreased from $0.0012 \pm 0.0031 \mathrm{~V}$ to a minimum value of $-0.1172 \pm 0.0152 \mathrm{~V}$, while the anode potential kept almost constant (Table S1), resulting in a warning signal by the alert system. Simultaneously, the effluent $\mathrm{NH}_{4}{ }^{+}-\mathrm{N}$ concentration of the AS reactor significantly increased from $0.25 \pm 0.18$ to $156 \pm$ $5.9 \mathrm{mg} / \mathrm{L}$, while the effluent COD concentration slightly increased from $22.8 \pm 3.6$ to $27.9 \pm 2.3 \mathrm{mg} / \mathrm{L}$ ( $\mathrm{P} 1$ in Fig. $3 \mathrm{~A}$ ). In addition, the DO concentration in the AS reactor decreased from $4.9 \pm 0.2$ to 3.6 $\pm 0.3 \mathrm{mg} / \mathrm{L}$. After the termination of the ammonia overloading shock, the variation of the MFC voltage was close to zero through 5-h operation (P2 in Fig. 3B). Meanwhile, the removal efficiencies of both $\mathrm{NH}_{4}{ }^{+}-\mathrm{N}$ and COD were constant in the AS reactor, indicating that the AS reactor was restored from the shock and reached a new steady state (P3 in Fig. 3).

On the other hand, the nitrate could be formed in the AS reactor due to nitrification, especially at a high ammonia concentration. Therefore, the nitrate effect on the accuracy of MFC-based online monitoring system was further investigated in this study. As shown in Fig. S2, the variation of MFC voltage was slight when $700 \mathrm{mg} / \mathrm{L}$ nitrate was introduced into the AS reactor, suggesting an insignificant effect of nitrate on the accuracy of the MFC-based online monitoring system.

Temperature shock. The variation of the MFC voltage during the temperature shock period is shown in Fig. 4 . When the temperature was decreased from $25.2^{\circ} \mathrm{C}$ to $10.3^{\circ} \mathrm{C}$ and $5^{\circ} \mathrm{C}$ at Hour 3 and Hour 5, the AS effluent $\mathrm{NH}_{4}{ }^{+}-\mathrm{N}$ concentration increased from $0.9 \pm 0.3$ to $8.3 \pm 1.5$ and $25.5 \pm 3.2 \mathrm{mg} / \mathrm{L}$ respectively, and the effluent COD level increased from $23.6 \pm 1.5$ to $38.8 \pm 4.5$ and $85.5 \pm 5.4 \mathrm{mg} / \mathrm{L}$ (Fig. 4A) respectively. Meanwhile, a substantial variation of the MFC voltage was observed with a minimum value of $-0.2767 \pm 0.0067 \mathrm{~V}$ after 5-h temperature shock (P1 in Fig. 4B), and the anode potential increased by $0.0884 \mathrm{~V}$ (Table S1). As a consequence, an early warning signal was given by the alert system at Hour 1.5 and

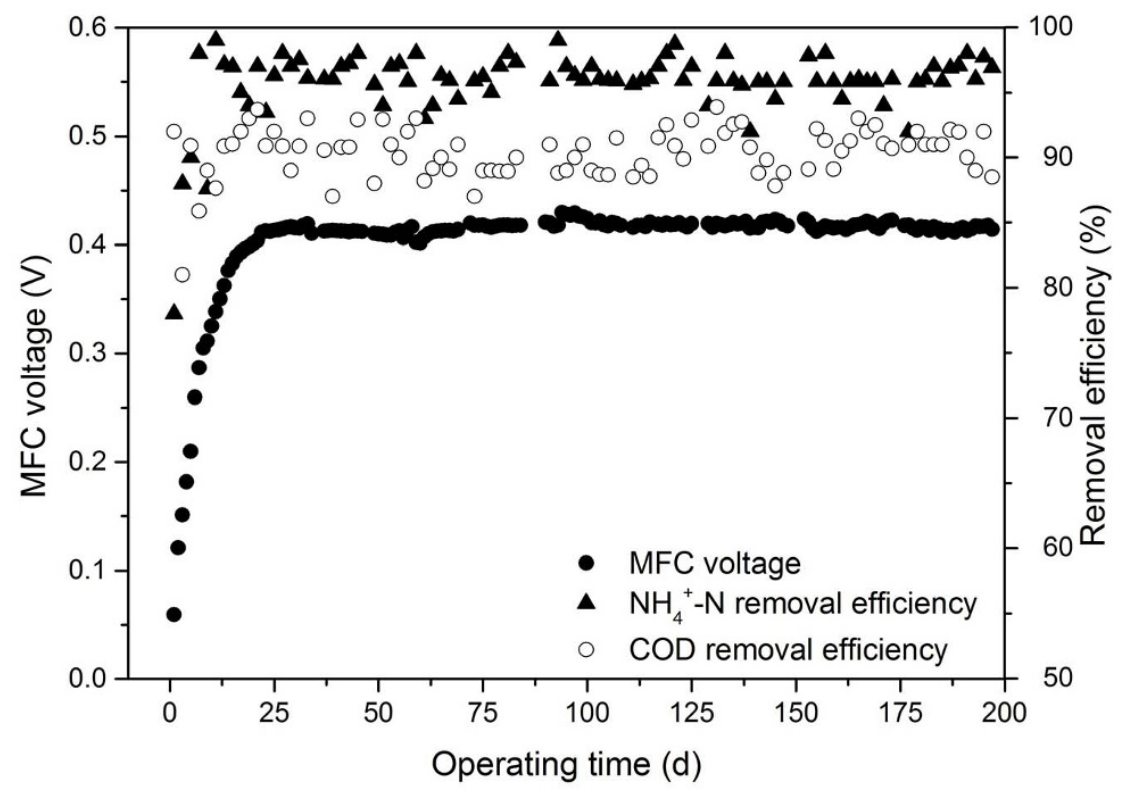

Figure $1 \mid$ Stability of the MFC-based online monitoring and alert system and the AS reactor without any shocks. 

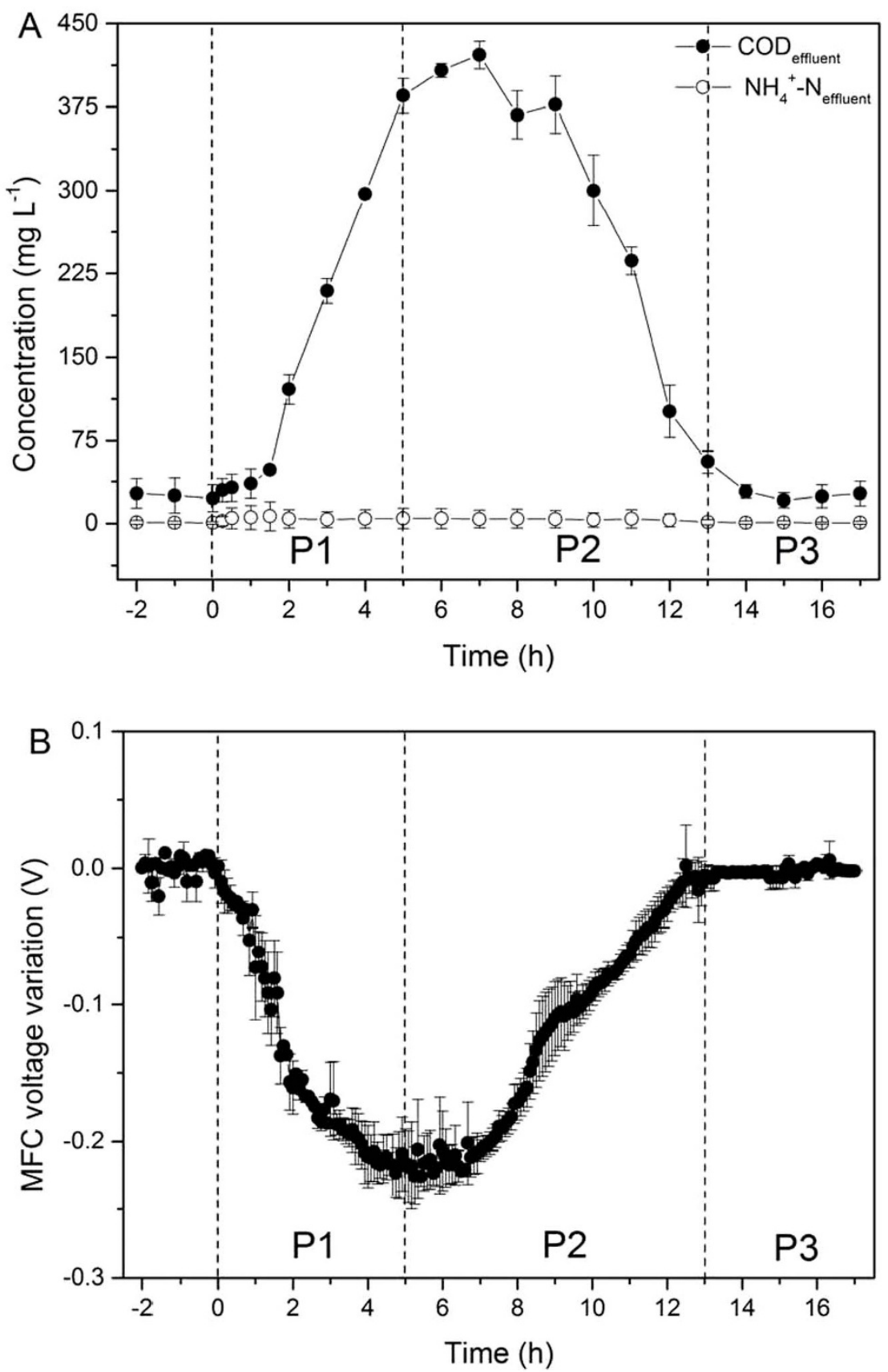

Figure $2 \mid$ Performance of MFC-based online monitoring and alert system under 10-fold organic overloading shock: $(A) \mathrm{COD}_{\text {effluent }}$ and $\mathrm{NH}_{4}{ }^{+}-\mathrm{N}_{\text {effluent }}$ of the AS reactor; and (B) MFC voltage variations.

lasted throughout P1. Within the temperature shock, the $\mathrm{NH}_{4}{ }^{+}-\mathrm{N}$ removal was completely inhibited in Hours $0-20$, and the MFC voltage was below $0.2 \mathrm{~V}$. At the end of temperature shock (P2), the variation of the MFC voltage drastically increased from $-0.28 \pm$ 0.018 to $0.0014 \pm 0.0008 \mathrm{~V}$, and a slow increase in the COD and $\mathrm{NH}_{4}{ }^{+}-\mathrm{N}$ removal efficiencies was observed. This result suggests the performance recovery of the AS reactor. As a result, the alert signal was stopped.

Toxicant loading shock. During the toxicant loading shock period (P1 in Fig. S3), the AS effluent COD concentration increased from $21.5 \pm 1.5$ to $115.8 \pm 6.5 \mathrm{mg} / \mathrm{L}$ with a corresponding decrease in removal efficiency from $92.8 \pm 0.5 \%$ to $61.4 \pm 2.2 \%$. At the same time, the effluent $\mathrm{NH}_{4}{ }^{+}-\mathrm{N}$ concentration increased from $0.8 \pm 0.12$ to $21.2 \pm 2.5 \mathrm{mg} / \mathrm{L}$ with a corresponding removal efficiency decline from $97.3 \pm 0.4 \%$ to $29.3 \pm 8.3 \%$ (Fig. S3A). These results indicate that cadmium chloride had a severe inhibition on the AS process, especially for COD and $\mathrm{NH}_{4}{ }^{+}$removals. On the other hand, the MFC had a rapid response to this toxicant shock and its voltage drastically reduced from $0.41 \pm 0.024$ to $0.06 \pm 0.002 \mathrm{~V}$ within $5 \mathrm{~h}$ (P1 in Fig. $\mathrm{S} 3 \mathrm{~B})$. Meanwhile, the anode potential increased by $0.1425 \mathrm{~V}$ (Table $\mathrm{S} 1)$. In this case, the variation of the MFC voltage was higher than the preset threshold value after the shock, a lasting alert signal was generated by the alert system. The sharp decrease in the MFC voltage indicates a severe collapse of the AS reactor in this toxicant shock. The AS reactor needed one week to recover after the termination of the toxicant shock.

\section{Discussion}

MFC-based "biosensor" technology has been recently developed to determine various individual parameters of water samples, while this study focused on the establishment of a novel MFC-based monitor- 

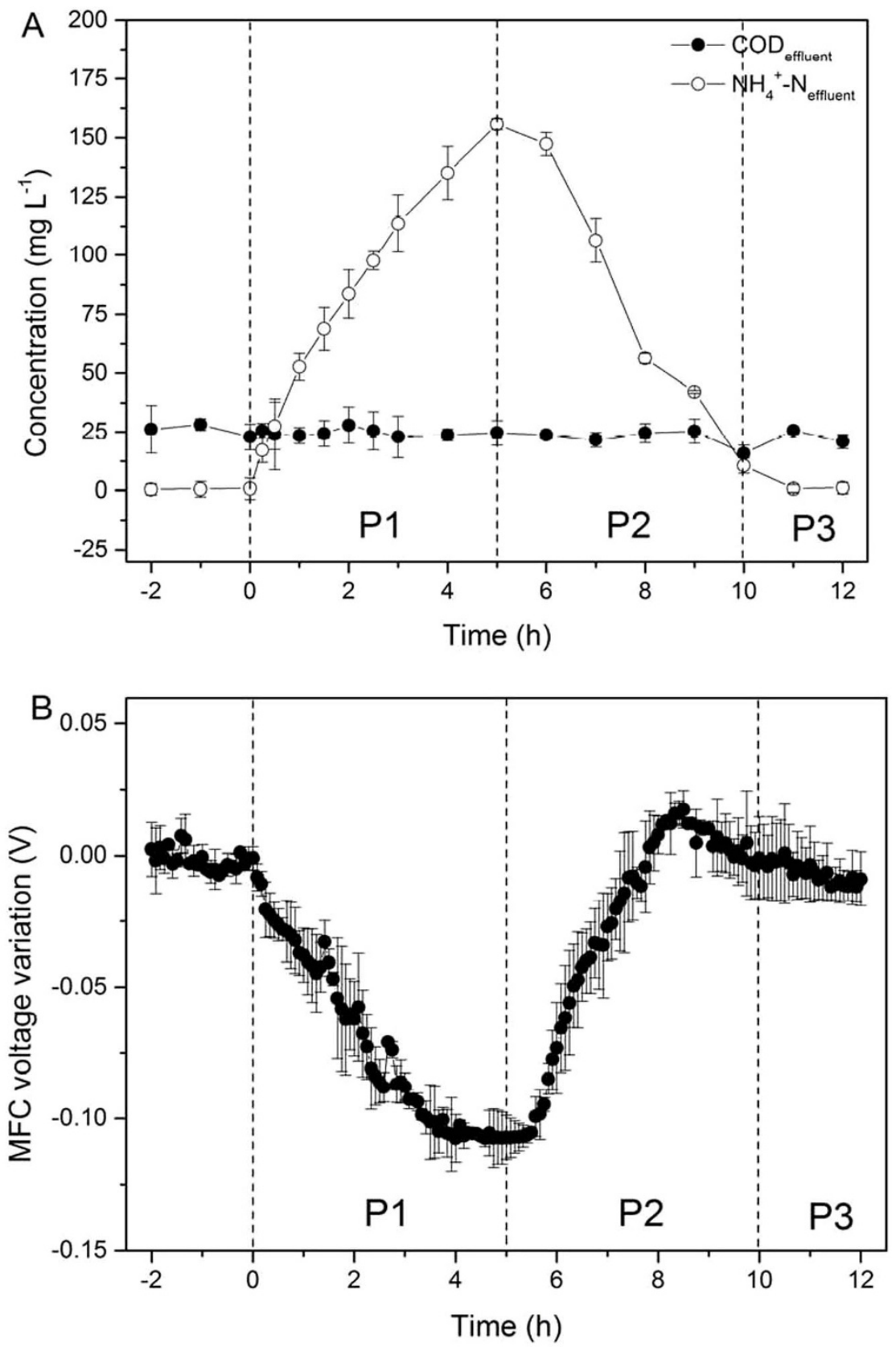

Figure 3 Performance of MFC-based online monitoring and alert system under 10-fold ammonia overloading shock: $(\mathrm{A}) \mathrm{COD}_{\text {effluent }}$ and $\mathrm{NH}_{4}{ }^{+}-$ $\mathrm{N}_{\text {effluent }}$ of the AS reactor; and (B) MFC voltage variations.

ing and alert system with self-diagnosis function rather than a biosensor for the AS process. The main differences between our MFCbased diagnosis monitoring and alert system with the MFC sensors reported in literature are summarized in Table S2.

The submerged single-chamber MFC was constructed with a novel design in this study, as shown in Fig. S4. The anodic microorganisms in the MFC could sustain themselves using substrate from the AS influent, while plenty of oxygen in the AS reactor could be adopted as the electron acceptor for the cathode of the submerged MFC. Thus, Such MFC design could not only provide evaluation on the status of the AS reactor, but also significantly reduce the costs of the online monitoring system, especially for a long-term operation. In addition, a new diagnosis and alert program was also developed to rapidly evaluate the AS reactor status based on the signals of MFC voltages, anode potential and operational temperature.
As an online monitoring and alert system, its signal should be stable when the AS reactor is operated at steady state. Otherwise, it would result in an incorrect conclusion. The signal of our developed system, i.e., the MFC voltage variation, was relatively stable under usual conditions and fluctuated only in a $5 \%$ range $( \pm 0.02 \mathrm{~V})$ over six months without any maintenance (Fig. 1). On the other hand, the MFC-based monitoring system demonstrated a high sensitivity to different shocks. For example, in the organic overloading shock tests, the decrease in the MFC voltage variation had a correlation with the increase in the AS effluent COD level (Fig. 2). The MFC voltage variation had a quick response to such an organic overloading shock.

This online monitoring and alert system also had a capability of early warning to various shocks. Here, we took the temperature shock test as an example. After 1.5-h shock (P1 in Fig. 4), the AS effluent $\mathrm{COD}$ and $\mathrm{NH}_{4}{ }^{+}-\mathrm{N}$ concentrations varied slightly from 23.6 \pm 1.5 to $34.7 \pm 2.5 \mathrm{mg} / \mathrm{L}$, and from $0.9 \pm 0.3$ to $2.3 \pm 0.7 \mathrm{mg} / \mathrm{L}$, 

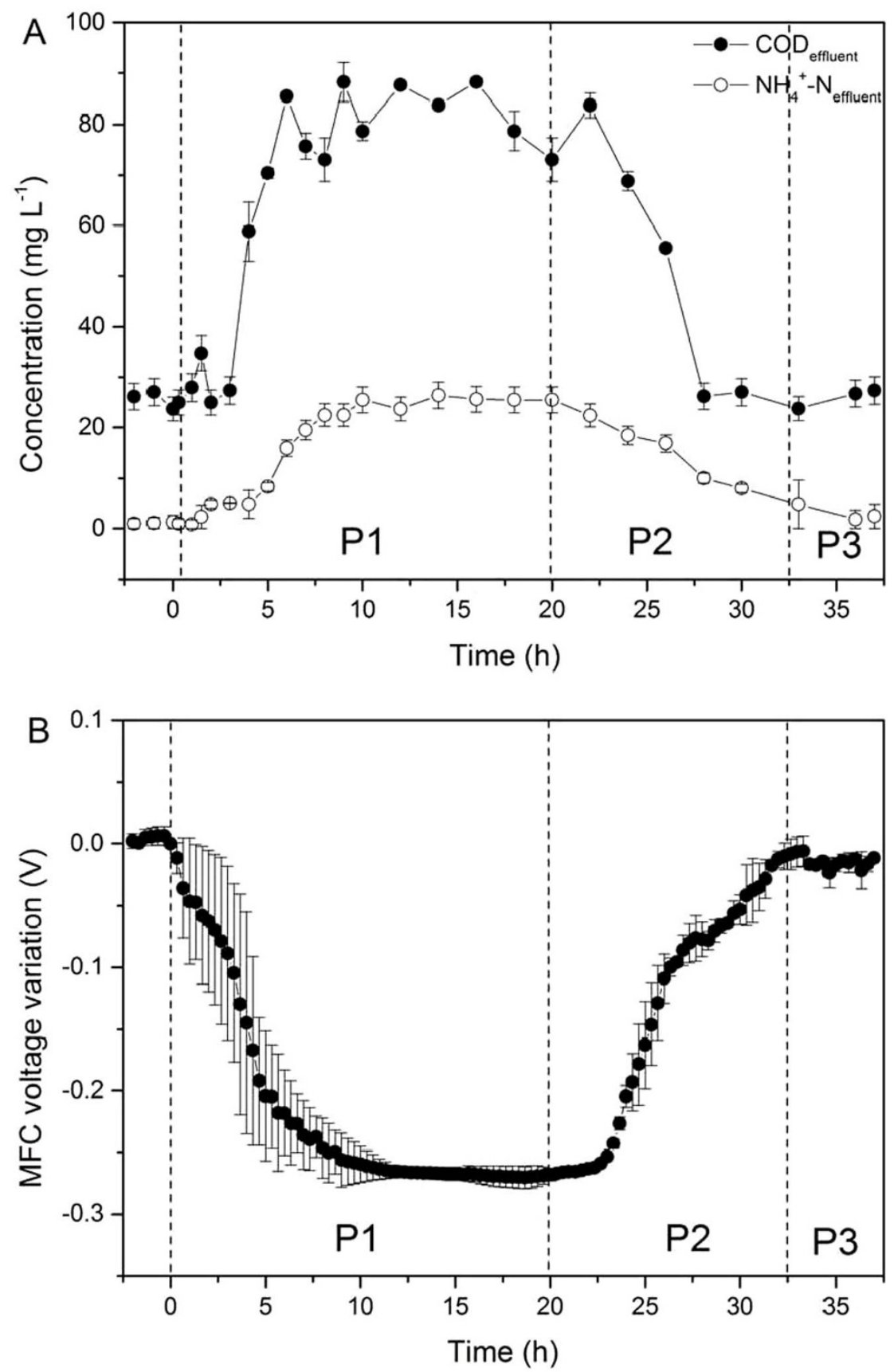

Figure $4 \mid$ Performance of MFC-based online monitoring and alert system under $5^{\circ} \mathrm{C}$ temperature shock: (A) $\mathrm{COD}_{\text {effluent }}$ and $\mathrm{NH}_{4}{ }^{+}-\mathrm{N}_{\text {effluent }}$ of the AS reactor; and (B) MFC voltage variations.

respectively (Fig. 4A). However, the voltage variation changed substantially: the voltage variation exceeded $0.04 \mathrm{~V}$ and decreased from $0.0013 \pm 0.001$ to $-0.0644 \pm 0.009 \mathrm{~V}$ (Fig. $4 \mathrm{~B})$. As a result, an early alert warning was given at Hour 1.5 (Table S1). On the other hand, the AS effluent COD and $\mathrm{NH}_{4}{ }^{+}-\mathrm{N}$ concentrations exceeded the China's Discharge Standard (COD $>60 \mathrm{mg} / \mathrm{L}$ or $\mathrm{NH}_{4}{ }^{+}-\mathrm{N}>$ $15 \mathrm{mg} / \mathrm{L}$ ) at Hour 6 (P1, Fig. 4). The warning signal given by the alert program was 4.5 hours earlier than the substantial deterioration of the effluent quality. Therefore, the MFC system could response more rapidly and provide an early alert warning. Additionally, the MFC voltage variations of two repeated tests were consistent, indicating that the MFC-based online system had a high repeatability for different shocks.

Furthermore, on the basis of MFC voltage, anode potential and operational temperature variations, a correlation between these three indexes and AS reactor status was established in order to address differentiation of various types of shocks (Table 1). The variation of MFC voltage alone was insufficient to determine what kind of shock the AS system suffered from, as its value was negative under all four types of shocks. However, the shock type suffered by the AS reactor could be identified through a comprehensive analysis of the variations of MFC voltage, anode potential and operational temperature. As shown in Table 1, a negative variation of both MFC voltage and anode potential means an organic overloading shock, while a negative MFC voltage variation with a positive anode potential variation indicates a toxicant or temperature one. Furthermore, the temperature and toxicant shocks could be distinguished through the variation value of operational temperature. Additionally, a negative variation of the MFC voltage with a constant anode potential implies that the AS reactor might suffer an ammonia overloading shock. 
Table 1 | Comprehensive analysis of MFC voltage, anode potential and operational temperature variations to identify shock type

\begin{tabular}{lccc} 
MFC voltage variation & Anode potential variation & Temperature variation & Shock type \\
\hline negative & negative & zero & organic overloading shock \\
negative & close to zero & zero & ammonia overloading shock \\
negative & positive & negative & temperature shock \\
negative & positive & zero & Toxicant shock
\end{tabular}

Compared with the conventional online monitoring systems, the new design MFC without CEM in our system could sustain itself using substrates in wastewater and thus reduce the costs of its long-term operation. In addition, the sensitivity of this online monitoring and alert system ensure a reliable early warning of potential risks, and the relative simplicity, stability and adaptability of this system provide high feasibility of being incorporated into current control systems for wastewater treatment plants.

\section{Methods}

AS reactor. As shown in Fig. S4, the cylindrical AS reactor had a working volume of $7.1 \mathrm{~L}$ with $30-\mathrm{cm}$ height and $11.5-\mathrm{cm}$ diameter. The AS reactor was inoculated with 7.1 L activate sludge from the Wangtang Municipal Wastewater Treatment Plant (Hefei, China), and the concentration of suspended solids (SS) and volatile suspended solids (VSS) was $2752 \pm 160$ and $2120 \pm 127 \mathrm{mg} / \mathrm{L}$, respectively.
MFC-based online monitoring and alert system. The established online monitoring and alert system included three parts: a single-chamber MFC, a signal acquisition subsystem and an alert subsystem with self-diagnosis function (Fig. 5). The schematic of the MFC is shown in Fig. S4. The nonwoven cloth was used as the separator of the cathodic and anodic chambers in the MFC. To prevent leakage, the nonwoven cloth was pretreated by tetrafluoroethylene as described previously ${ }^{18,19}$, and was supported with a polyvinyl chloride tube. The total empty volume of the anodic chamber was $636 \mathrm{~mL}$. Granular graphite with a diameter of 3-5 mm (Sanye Carbon Co., China) was used as the electrode material in the anode compartment, reducing the compartment liquid volume to $145 \mathrm{~mL}$. In addition, a graphite rod with $6 \mathrm{~mm}$ diameter (Sanye Carbon Co., China) was inserted into the anode compartment for connection. A $\mathrm{Ag} / \mathrm{AgCl}$ reference electrode was inserted into the anode chamber for monitoring anode potential. A $0.6-\mathrm{cm}$ thickness carbon-graphite felt with $380 \mathrm{~cm}^{2}$ of surface area (Sanye Carbon Co., China) was used as the cathode material without any pretreatment. The graphite rod and carbon felt were connected by titanium wires across an external resistance $(100 \Omega)$. The $50-\mathrm{mL}$ inoculated sludge of the MFC was the concentrated

\section{Alert subsystem with self-diagnosis function}
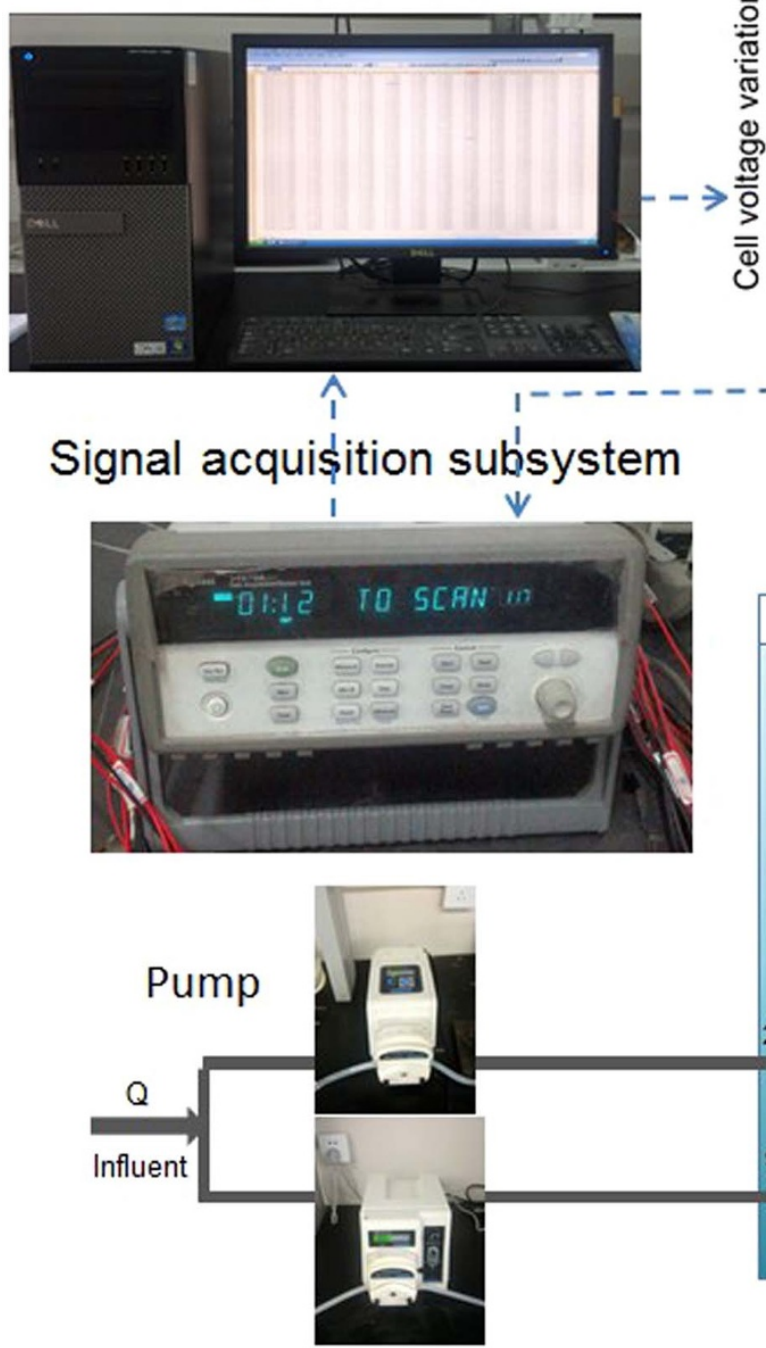
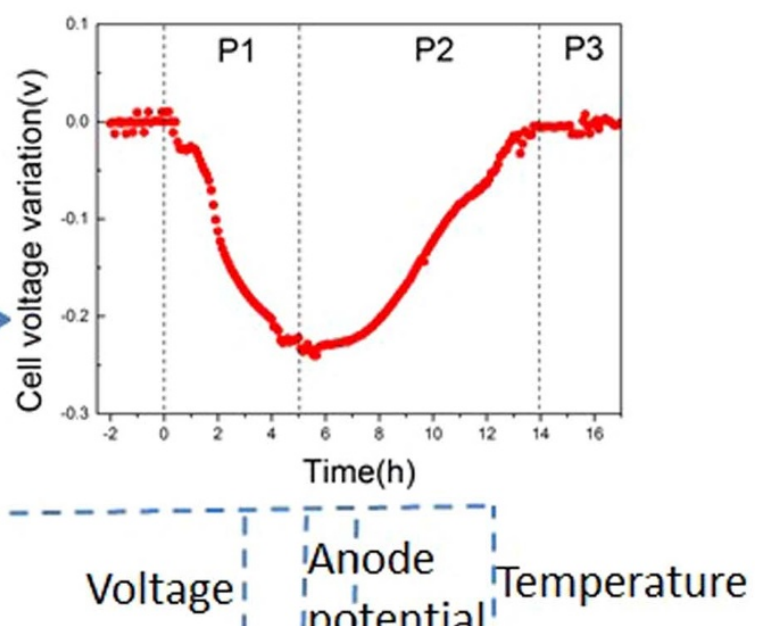

$2 \% Q$

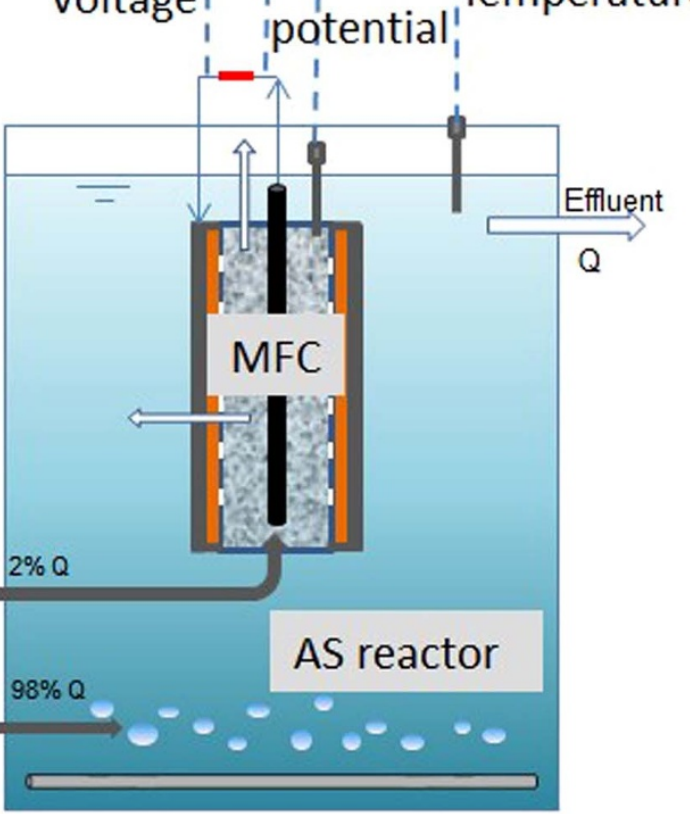

Figure $5 \mid$ Schematic of the MFC-based online monitoring and alert system. 
Table 2 | Experimental condition for various shock tests

\begin{tabular}{|c|c|c|c|}
\hline Run & Test & Duration & Shock operating conditions \\
\hline $35-38 d$ & 10-fold organic overloading shock & $36 \mathrm{~h}$ & $\begin{array}{l}\text { influent COD } 3000 \mathrm{mg} / \mathrm{L} \text {; influent } \mathrm{NH}_{4}{ }^{+}-\mathrm{N} 30 \mathrm{mg} / \mathrm{L} \text {; HRT } 5 \mathrm{~h} \text {; temperature } 25^{\circ} \mathrm{C} \text {; } \\
\text { influent conductivity } 4390 \pm 527 \mu \mathrm{s} / \mathrm{cm}\end{array}$ \\
\hline $47-49 d$ & 10-fold ammonia overloading shock & $25 \mathrm{~h}$ & $\begin{array}{l}\text { influent COD } 300 \mathrm{mg} / \mathrm{L} \text {; influent } \mathrm{NH}_{4}{ }^{+}-\mathrm{N} 300 \mathrm{mg} / \mathrm{L} ; \text { HRT } 5 \mathrm{~h} \text {; temperature } 25^{\circ} \mathrm{C} \text {; } \\
\text { influent conductivity } 2025 \pm 325 \mu \mathrm{s} / \mathrm{cm}\end{array}$ \\
\hline $85-90 d$ & $5^{\circ} \mathrm{C}$ temperature shock & $80 \mathrm{~h}$ & $\begin{array}{l}\text { influent COD } 300 \mathrm{mg} / \mathrm{L} \text {; influent } \mathrm{NH}_{4}{ }^{+}-\mathrm{N} 30 \mathrm{mg} / \mathrm{L} \text {; HRT } 5 \mathrm{~h} \text {; temperature of } 5^{\circ} \mathrm{C} \text {; } \\
\text { influent conductivity } 785 \pm 185 \mu \mathrm{s} / \mathrm{cm}\end{array}$ \\
\hline $109-114 d$ & Toxicant shock & $370 \mathrm{~h}$ & $\begin{array}{l}\text { influent COD } 300 \mathrm{mg} / \mathrm{L} \text {; influent } \mathrm{NH}_{4}{ }^{+}-\mathrm{N} 30 \mathrm{mg} / \mathrm{L} \text {; cadmium chloride } 500 \mathrm{mg} / \mathrm{L} \text {; } \\
\text { HRT } 5 \mathrm{~h} \text {; temperature } 25^{\circ} \mathrm{C} \text {; influent conductivity } 1454 \pm 210 \mu \mathrm{s} / \mathrm{cm}\end{array}$ \\
\hline
\end{tabular}

anaerobic sludge with an SS concentration of $10 \mathrm{~g} / \mathrm{L}$ from an upflow anaerobic blanket reactor at our laboratory.

A data acquisition subsystem (34970A, Agilent Co., USA) was used to real-time collect and record MFC voltage, anode potential and operational temperature every $5 \mathrm{~min}$. Based on the statistical analysis and logic judgment programs, the alert system with self-diagnosis function was developed with a LabView virtual instrument platform (National Instruments Co., USA) as described previously ${ }^{20}$. In this alert program, the variation value of MFC voltage was calculated as the voltage value at a certain time minus the average one at steady state. An absolute value of MFC voltage variation lower than the pre-set threshold value of $0.04 \mathrm{~V}$ (Page 2-3 in SI) indicated a steady state of the AS process. If the absolute value of MFC voltage variation exceeded the pre-set threshold value of $0.04 \mathrm{~V}$, a warning signal would be given by this alert system to indicate possible risks for the AS reactor. Moreover, a higher absolute value of MFC voltage variation means a higher degree of risk for the AS reactor.

Experimental operation. Under normal conditions, the HRT (hydraulic retention time) of the AS reactor was kept at $5 \mathrm{~h}$. The synthetic wastewater was separately fed into the AS reactor and the anode of the submersible MFC with a flow rate of 1421 and $29 \mathrm{~mL} / \mathrm{h}$, respectively. The compositions of the synthetic wastewater were as follows: $0.64 \mathrm{~g} / \mathrm{L} \mathrm{CH} \mathrm{COONa}_{3} 3 \mathrm{H}_{2} \mathrm{O} ; 0.125 \mathrm{~g} / \mathrm{L} \mathrm{NH}_{4} \mathrm{Cl} ; 0.1 \mathrm{~g} / \mathrm{L} \mathrm{KH}_{2} \mathrm{PO}_{4} ; 12 \mathrm{mg} / \mathrm{L} \mathrm{CaCl}$; $12 \mathrm{mg} / \mathrm{L} \mathrm{MgSO}_{4}$; and $10 \mathrm{~mL}$ of trace element solution as described previously ${ }^{19}$. The SS concentration of the AS rector was $4516 \pm 282 \mathrm{mg} / \mathrm{L}$ and the solids retention time (SRT) was kept at $20 \mathrm{~d}$ through discharging excess sludge (Fig. S5). DO and pH in the AS reactor were $4.4-5.1 \mathrm{mg} / \mathrm{L}$ and $6.7-7.2$, respectively. The conductivity of AS reactor was $985 \pm 212 \mu \mathrm{s} / \mathrm{cm}$ under normal conditions, and the influent conductivity under different shocks is listed in Table 2.

A series of shock tests were conducted for the AS reactor, as summarized in Table 2. The influent COD concentration was increased by 10 times for the organic overloading shock. The ammonia overloading shock was imposed by switching the feed $\mathrm{NH}_{4}{ }^{+}-\mathrm{N}$ concentration by 10 fold. For the temperature shock, the reactor was put into a freezer at $5^{\circ} \mathrm{C}$. Cadmium chloride with $500 \mathrm{mg} / \mathrm{L}$ was imposed into the AS reactor for the toxicant shock. Each shock test was repeated twice.

Analysis. The concentrations of SS, VSS, COD, $\mathrm{NH}_{4}{ }^{+}-\mathrm{N}$, and temperature were measured according to the APHA standard methods ${ }^{21}$. DO and $\mathrm{pH}$ value were determined by a portable DO/pH meter (HQ 40d, Hach Co., USA). The conductivity of influent was measured by a conductivity meter (DDSJ-308A, INESA Scientific Instrument Co., China). The polarization curves of MFC were obtained by an electrochemical workstation (CHI660C, Shanghai Chenhua Co., China) at a scan rate of $1 \mathrm{mV} / \mathrm{s}$ and a prior open circuit potential period of $12 \mathrm{~h}$. The current density and power density were normalized to the total anodic chamber volume. The $\mathrm{CE}$ was calculated as described previously ${ }^{19}$.

1. van Loosdrecht, M. C. M. \& Brdjanovic, D. Anticipating the next century of wastewater treatment. Science 344, 1452 (2014).

2. Vanrolleghem, P. A., Sin, G. \& Gernaey, K. V. Transient response of aerobic and anoxic activated sludge activities to sudden substrate concentration changes. Biotechnol Bioeng. 86, 277-290 (2004).

3. Vaiopoulou, E. \& Gikas, P. Effects of chromium on activated sludge and on the performance of wastewater treatment plants: A review. Water Res. 46, 549-570 (2012).

4. Archibald, F. et al. A simple system to rapidly monitor activated sludge health and performance. Water Res. 35, 2543-2553 (2001).

5. Gernaey, K. et al. On-line nitrification monitoring in activated sludge with a titrimetric sensor. Environ Sci Technol. 31, 2350-2355 (1997).

6. Modin, O. \& Wilén, B. M. A novel bioelectrochemical BOD sensor operating with voltage input. Water Res. 46, 6113-6120 (2012).

7. Zhang, Y. \& Angelidaki, I. A simple and rapid method for monitoring dissolved oxygen in water with a submersible microbial fuel cell (SBMFC). Biosens Bioelectron. 38, 189-194 (2012).

8. Logan, B. E. \& Elimelech, M. Membrane-based processes for sustainable power generation using water. Nature 488, 313-319 (2012).
9. Logan, B. E. \& Rabaey, K. Conversion of wastes into bioelectricity and chemicals by using microbial electrochemical technologies. Science 337, 686-690 (2012).

10. Yuan, S. J. et al. A plate-based electrochromic approach for the high-throughput detection of electrochemically active bacteria. Nature Protocols. 9, 112-119 (2014).

11. Pant, D. et al. Bioelectrochemical systems (BES) for sustainable energy production and product recovery from organic wastes and industrial wastewaters. RSC Adv. 2 , 1248-1263 (2012).

12. Feng, L. Y. et al. Enhancing electrocatalytic oxygen reduction on nitrogen-doped graphene by active sites implantation. Scientific Reports. 3, 3306 (2013).

13. Wang, Y. P. et al. A microbial fuel cell-membrane bioreactor integrated system for cost-effective wastewater treatment. Appl Energy. 98, 230-235 (2012).

14. Di Lorenzo, M. et al. A single-chamber microbial fuel cell as a biosensor for wastewaters. Water Res. 43, 3145-3154 (2009).

15. Kaur, A. et al. Microbial fuel cell type biosensor for specific volatile fatty acids using acclimated bacterial communities. Biosens Bioelectron. 47, 50-55 (2013).

16. Wang, X. Gao, N. S. J. \& Zhou, Q. X. Concentration responses of toxicity sensor with Shewanella oneidensis MR-1 growing in bioelectrochemical systems. Biosens Bioelectron. 43, 264-267 (2013).

17. Ghangrekar, M. M. \& Shinde, V. B. Performance of membrane-less microbial fuel cell treating wastewater and effect of electrode distance and area on electricity production. Bioresour Technol. 98, 2879-2885 (2007).

18. Cheng, S. Liu, H. \& Logan, B. E. Power densities using different cathode catalysts (Pt and CoTMPP) and polymer binders (Nafion and PTFE) in single chamber microbial fuel cells. Environ Sci Technol. 40, 364-369 (2006).

19. Wang, Y. K. et al. Development of a novel bioelectrochemical membrane reactor for wastewater treatment. Environ Sci Technol. 45, 9256-9261 (2011).

20. Dong, F. et al. Novel online monitoring and alert system for anaerobic digestion reactors. Environ Sci Technol. 45, 9093-9100 (2011).

21. APHA Standard methods for the examination of water and wastewater $20^{\text {th }}$ Washington, DC, American Public Health Association, 1998.

\section{Acknowledgments}

The authors wish to thank the National Science Foundation of China (51208488 and 51222812), the Recruitment Program of Global Experts, and the Program for Changjiang Scholars and Innovative Research Team in University of the Ministry of Education of China for the partial support of this work. The authors have no conflict of interests to declare.

\section{Author contributions}

G.H.X. carried out the experiments, analyzed the data, and wrote the paper; Y.K.W. and G.P.S. analyzed the data; H.Q.Y. and Y.M. designed the experiments, analyzed the data, and wrote the paper.

\section{Additional information}

Supplementary information accompanies this paper at http://www.nature.com/ scientificreports

Competing financial interests: The authors declare no competing financial interests.

How to cite this article: Xu, G.-H., Wang, Y.-K., Sheng, G.-P., Mu, Y. \& Yu, H.-Q. An MFC-Based Online Monitoring and Alert System for Activated Sludge Process. Sci. Rep. 4, 6779; DOI:10.1038/srep06779 (2014).

This work is licensed under a Creative Commons Attribution-NonCommercialNoDerivs 4.0 International License. The images or other third party material in this article are included in the article's Creative Commons license, unless indicated otherwise in the credit line; if the material is not included under the Creative Commons license, users will need to obtain permission from the license holder in order to reproduce the material. To view a copy of this license, visit http:// creativecommons.org/licenses/by-nc-nd/4.0/ 